\title{
2005년 World Economic and Social Survey
}

1 10.10(월) Ocampo 유엔 경제사회 담당 사무차장 은 개발재원에 관한 2005년 World Economic and Social Survey 보고서를 발표한 바, 동 보고 서는 몬테레이 컨센서스에 담겨 있는 개발재원의 주요 구성요소(국내재원 동원, 무역, 민간 자본, 공 적개발재원, 외채, 국제금융시스템)에 관한 진전 상황 등을 수록하고 있음. 동 보고서 중 우리의 개 도국 개발지원 관련 주목할 만한 ODA 및 외채 문 제에 관한 주요 보고서 내용은 아래와 같음.

(동 보고서 전문은 http://www.un.org/esa/ policy/wess/wess2005files/wess2005web.pdf 에 게재되어 있음).

\section{가. 공적개발재원}

$\square \mathrm{ODA}$ 는 1960년대 선진국 $\mathrm{GNI}$ 의 $0.5 \%$ 에 달하며 최 고조를 이루다가 밀레니엄 선언 당시 $0.21 \%$ 까지 하 락하였으나, 몬테레이 컨센서스를 통해 0.7\% ODA 목표 설정후 2003년과 2004년 0.25\%로 상승함.
- 그럼에도 불구, 2006- 10년 ODA 예상치는 2015년까지 MDGs 달성을 위한 필요 재원 마련 을 위해 여전히 미달

$\square$ 아난 사무총장은 모든 선진국이 2015년까지 GNI 의 $0.7 \%, 2009$ 년까지 $0.5 \%$ 목표 달성을 위한 시 간 계획을 마련할 것을 촉구한 바 있음.

$\square$ 현재까지 덴마크, 룩셈부르크, 네덜란드, 노르웨 이, 스웨덴만 $0.7 \%$ 를 충족시키기거나 상회하고 있 으며, 최근 EU 15 개 회원국은 2015년까지 0.7\%, 2010 년까지 $0.51 \%$ 목표 달성을 정한 바 있음.

- 2002년 이후 EU에 가입한 국가들은 2010년까 지 GNI의 $0.17 \%, 2015$ 년까지 $0.33 \%$ 목표를 달 성하도록 노력하는 데 합의

1990 년대 최빈국에 대한 ODA 지원은 당초 최빈 국(LDC)을 위한 브뤼셀 행동계획에서 목표한 $0.150 .2 \%$ 지원 목표의 절반 밖에 되지 못하였으 나, 몬테레이 컨센서스 이후 이러한 경향은 역전 되어 최빈국에 대한 ODA가 급증하였으며, 
2002 03년간 8개 선진국은 동 목표를 달성함.

$\square$ 그러나, 최근의 ODA 지원 증가에도 불구하고 $\mathrm{ODA}$ 는 개도국의 예산직접지원(budgetary support)으로서는 오히려 감소하는 경향을 보이 고 있는 바, ODA 지원이 MDGs 달성을 위한 효과 적인 수단으로 전환되기 위해서는 수혜국의 예산 재원에 반영되도록 지원되는 것이 필요함.

몬테레이 컨센서스 후속조치로서 ODA를 보충할 수 있는 새로운 개발재원 마련을 위한 이니셔티브 가 브라질, 프랑스, 칠레 등에 의해 제안되었으며, 참가국들의 채권 발행을 통해 개발 재원을 우선 지원하는 국제개발재원기구(IFF) 설립 방안이 영 국에 의해 제안되었음.

- 이외의 새로운 개발 재원 마련 방안으로서 환경, 국제금융거래, 항공티켓 등에 국제적으로 합의 된 세금을 부과하는 방안과 개발 목적을 위한 특 별인출권(SDR) 할당 등의 다양한 방안이 제안되 었으며, 이중 국제금융거래와 환경 분야에 부과 되는 국제 조세가 장기적으로 가장 많은 추가 개 발재원을 마련하는 방안으로 나타나고 있음.

- 그러나 이러한 방안들에 대해 회원국들간 완전 한 합의를 이루어내기는 어려울 것인 바, 우선 지역적으로 합의가 가능한 범위에서 사업을 추 진하고 추후 다른 지역으로 확대하는 것이 필요 할 것임. 이와 관련 유럽 재무장관들은 HIV/AIDS 대처 자금 마련을 위해 항공권에 자 발적 세금을 부과하는 pilot project 제안을 고 려하고 있음.

- 이러한 새로운 개발 재원 마련 방안들은 엄격히
ODA 목표 달성 공약에 추가적이고 보충적인 것이 되어야 한다는 강조되고 있음.

나. 외채

$\square$ 몬테레이 컨센서스에서 확인된 바와 같이 외채 경 감은 개발을 위한 국내재원 동원을 위한 효과적인 방안임.

1996년 최빈국들의 외채 문제 해결을 위해 출범된 고채무빈국(HIPC) 이니셔티브에 의해 현재까지 27 개 고채무빈국들이 외채경감을 받았음(2005년 G- 8 정상 합의에 따라 18 개국이 국제금융기구의 외채탕감 혜택의 수혜함).

- 그러나 이러한 성과에도 불구하고 몇몇 최빈국 들의 부채는 증가하는 현상을 보이는 바, 이는 $\mathrm{GDP}$ 증가, 수출, 물가 등에 관한 당초의 가정들 이 너무 낙관적이었던 것에 기인함.

$\square$ 고채무빈국 외채 경감 프로세스가 MDGs 달성에 결정적인 재원을 마련할 수 있었다는 것은 확실하 나 이는 여전히 필요한 만큼에 미치지 못하고 있음. - 2005년 사무총장 보고서는 외채의 지속 가능성 (debt sustainability)으로 한 국가가 외채 비율 을 늘리지 않고 2015년까지 MDGs를 달성할 수 있는 외채 수준을 제안하고 있음.

- 이렇게 되기 위해서는 고채무빈국의 경우에는 무상원조에 기반한 개발자금 지원과 $100 \%$ 외채 탕감이 필요함.

$\square$ non- HIPC 국가나 중소득 국가들의 경우에는 이 제까지 제안된 것보다 더 많은 상당한 부채경감이 이루어져야 함. 이제까지 이들 국가의 외채경감과 
관련하여 별다른 논의가 없었으나, 파리 클럽의

“ Evian Approach"와 같이 이들 국가들에 대한 외채적용 범위에 더 많은 여지를 주는 새로운 메 커니즘이 제안되어 있음.

$\square$ 외채 완전 탕감 이후 외채의 장기적인 지속 가능성 은 해당국의 수출과 경제성장 전망에 달려 있음. 그러므로 외채 문제는 무역, 금융 등과 함께 하나 의 틀 속에서 다루어져야 하며 개도국의 부채 문제 해결을 위한 지속적인 방안과 개도국의 외채 관리 능력을 강화하는 방안도 강구되어야 할 것임.

$\square$ 1990년대 이후 민간분야에 있는 파산법에 기초한 국제적인 외채 해결 방안에 대한 논의가 이루어져 온 바, 자발적인 규약, 국제 주선 및 중재 등을 포 함한 외채 해결 메커니즘을 마련해 나가는 것이 중 요함. 이와 관련 최근 다수의 외채국들이 집단행동 조항(CACs)을 채택한 것은 매우 긍정적인 조치임.

2. 한편 제2위원회는 10.7(금) 하버드 Kennedy School 의 Dani Rodrik 교수를 초청하여 In Search of Prosperity:a view on national growth strategies"에 대한 토의를 가진 바, Rodrik 교수의 발언 요지 및 토의 주요내용은 아래와 같음.

\section{가. Rodrik 교수 발언 요지}

1970 80년대에는 소위 Washington Consensus (이하 WC)가 있었으나 다음과 같은 요인으로 더 이상 WC를 주장하는 개발학자는 없어졌음.

- WC는 중남미 경제에 대한 권고를 하는 과정에 서 관세 및 금융시장 자유화, 거시경제 안정화
정책, 사유화를 강조하였으며, 이후 기업지배구 조, 노동시장의 유연성, 금융시장의 prudential regulation 및 변동환율제 채택을 권고하는 내 용임.

- 그러나 90년대 들어와 동 권고를 충실히 이행한 중남미 국가의 경제시장은 더욱 나빠지고, 전통 적 방식을 따르지 않은 중국, 인도, 베트남이 부 상함(평균관세 : 중국 31\%, 베트남 30 50\%, 인 도 $50 \%)$.

$\square$ 이러한 결과에 따라 경제학자들은 (1)자신들이 제 안하는 개발정책은 한계가 있으며, (2)가장 중요한 것은 일반화된 개발정책보다는 각국의 국내상황에 맞추어 정책을 추진해 나가되, (3)창의성을 가지고 선구적인 정책을 추진하는 것이 중요함을 확인함.

$\square$ 향후 개발정책을 추진함에 있어 (1)개별국가의 성 장을 저해하는 요소를 찾아내어(growth diagnostics), (2)거기에 적합한 정책대안을 마련 하고(policy design), (3)이를 제도화해 나가야 함. (institutionalization)

나. 토의 주요 내용

$\square$ 이러한 주제 발표에 대해 개도국 대표(자메이카 등)들은 IMF의 conditionality가 개별 개도국의 경제실정을 도외시한 채 일반화된 정책을 강요하 고 있다고 하면서 시정을 요구함.

- Rodrik 교수는 베트남의 예를 들면서 미국의 80 90년대초 경제제재 및 현재까지 WTO 미가 입 등 제약요인에도 불구하고 베트남의 독자적 인 노력으로 외국인 투자유치 및 무역을 통한 
경제개발에 성공하였음을 상기시키면서 개별 개도국의 노력이 필요함을 강조함.

$\square \mathrm{EU}$ 대표(영국)은 현재 개발문제는“ 워싱턴 컨센서 스"가 아니라 몬테레이 컨센서스"에 의해 규율되 고 있으며 선진국의 ODA 증가 및 빈국 친화정책 과 개도국의 good governance, 투명성 및 책임 제고가 심도있게 논의중임을 지적함.

[자료 : 주국제연합 대표부] 